\title{
Effect of Globalization on Income Inequality in Ghana
}

\author{
Christiana Manu ${ }^{1}$ \\ ${ }^{1}$ Marketing Department, Faculty of Business, Accra Technical University, Accra, Ghana \\ Correspondence: Christiana Manu, Marketing Department, Faculty of Business, Accra Technical University, \\ Accra, Ghana. Tel: 020-816-9950. E-mail: cmanu@ atu.edu.gh
}

Received: November 4, 2020

Accepted: December 10, 2020

Online Published: January 5, 2021

doi:10.5539/ijef.v13n2p15

URL: https://doi.org/10.5539/ijef.v13n2p15

\begin{abstract}
Available empirical evidence suggests that globalisation in recent years have had a significant positive impact on various sectors of most economies; however, significant evidence also exists suggesting that this economic process has also accentuated poverty and worsened income distribution in parts of some economies. This study examines the effects of foreign direct investment, trade openness and foreign remittance on income inequality in Ghana. The paper applied the vector error correction model in examining the effect of FDI inflow, foreign remittance and trade openness and income inequality in Ghana. The result indicates Foreign Remittance, FDI, Trade Openness and Gini index, are integrated of order one. Additionally, Johansen's test for cointegration suggest a long-run relationship between the Gini coefficient (income distribution) and examined independent variables. The study also found out that foreign remittance has a significant negative relationship with Ghana's income inequality and FDI inflows have no significant impact on Ghana's income inequality.
\end{abstract}

Keywords: Gini coefficient, income inequality, Ghana, FDI, trade openness, foreign remittance

\section{Introduction}

\subsection{Introduce the Problem}

Globalization appears to have coincided with growing income inequality among both developed and developing countries. Globalization has led to significant changes in how business is conducted and how organizations operate internationally. Globalization has created opportunities in terms of access to larger pools of resources as well as different markets for both economies and corporations (Stromquist \& Monkman, 2014). Companies such as IBM, Intel, Microsoft, and Philips can be found all over the world, creating job and improving the economy of host countries (Sarti, 2016). Globalisation is the process of the rapid economic integration of economies, driven by technological change, trade liberalization as well as investment and capital flows (Pieterse, 2015). Brambilla, Laine, and Bocchi (2016) defined globalization as a multi-dimensional tool that influences a country's income distribution. Alliances involving automakers (GM-Ford- Daimler Chrysler, Ford-Mazda, and GM-Honda), petroleum manufacturers (e.g., BP-Mobil, NUPI-Chevron Texaco), and airlines (e.g., star alliances) are instances of observed modifications as a result of globalisation.

Concerns over the possible relationship between foreign direct investment (FDI); a product of globalisation and within-country income disparities are often prevalent in present-day political discussion, major media coverage and scholarly discussions (Couto \& Center, 2018). According to Ngwakwe and Dzomonda (2018), income inequality mitigates social and economic growth in developing countries; thus, one of the economic growth planning policies of governments has centred on reducing income inequality and accelerating of rural dependent growth. According to Benería, Berik, and Floro (2015), globalization has promoted the growth of average incomes in developing countries. However, the quality of life of the fewer privileged in the developing countries can reduce if incorporation into the world's economic system negatively impacts the income dissemination. With regards to trade openness, Hipsher (2017), found that activities of multinational corporations tend to escalate income inequality in developing nations, increasingly degrading the world's poor. Flach and Janeba (2017), found that FDI inflows in developing countries over ten years correlate positively with income inequality.

In furtherance of globalization, new reforms continue to be established purposely to create the enabling environment for the large market and freer external trade. Countries across the globe continue to establish continuously closer relations as time goes on, with the stride exorbitantly increasing in recent times (Hirst, Thompson, \& Bromley, 2015). In international trade and immigration, theoretical and empirical research have 
traversed how the flow of goods and people influence the trade balance of the nation. According to Kirby (2013), globalisation may have a positive impact on beneficiaries, but can also accentuate poverty and worsened income distribution in parts of the country.

\subsection{Problem Statement}

Ghana in the last two decades has significantly improved economic performance as a result of its interaction with other countries and foreign partners (Wilhelmina, Joost, George, \& Guido, 2010). The impact of globalisation has been studied in the balance of trade and movement of goods and services in studies such as Bhagwati and Srinivasan (2002); Surugiu and Surugiu (2015); Antràs, De Gortari, and Itskhoki (2017); however, its effect has not been observed in the area of distributions of income among emerging economies such as Ghana. This study used Gini Index (made up of decomposed income sources rather than consumption employed by other studies from the limited amount of available data on income groups in Ghana) to examine effects of foreign direct investment, trade openness and foreign remittance on income inequality in Ghana. The study also incorporates Knowledge-capital model as done in Darkwah et al. (2016a).

\subsection{Research Hypotheses}

The study is guided by the following null hypotheses;

1) $H_{0}$ : There is no significant relationship between foreign remittance and income inequality.

2) $H_{0}$ : There is no significant relationship between FDI inflows and income inequality.

\subsection{Literature Review}

This section reviews and analysed related literature with the price goal of highlighting how existing studies examined similar relationships. Several related studies on globalisation, Gini Indexes and trade agreements are subsequently discussed. Fouquin, and Hugot (2016), researched the First Globalization and Second Globalization of the nineteenth century. The number of years spanned for the study was from 1827 to 2014 with more than 1.9 million bilateral trade observations. The variables used for the study were exchange rate, trade flows, geographical distance, GDP, import, export and colonial and linguistic.

Surugiu and Surugiu (2015), studied effects of increased international trade over the years as a consequence of globalization opined that International trade can enhance the economic development of nations which are interlinked and that globalization cannot be ignored by corporations, because to the prospects provided by international economies. Dollar and Kraay (2004), assumed that trade encourages growth without increasing inequality, however, Bergh and Nilsson (2014) opined that though there is an impoverishment-reduction impact of globalization, just a tiny proportion of it is accounted for by growth and that it appears globalization decreases abject poverty, and not predominantly through the growth path.

Antràs, De Gortari, and Itskhoki (2017) investigating wellbeing impacts of trade opening in a global economy where trade boosts aggregate income whiles also enhancing income inequality suggested two changes to standard indicators of the welfare gains from trade: a welfare-oriented correction driven by the Atkinson (1970) index of inequality, and a costly-redistribution correction which considered the cost of productive output correlated with agents' behavioural reactions to trade-induced changes through marginal tax rates. They provided evidence that indicates that both remedies are important: trade-induced rises in rejection income inequality dissolve about 20 per cent of trade gains, while trade gains will be about 15 per cent greater if the distribution were carried out by non-distortionary means.

Couto and Center (2018) assessed the effect of FDI on income inequality for many countries in various phases of economic growth. For low-income nations, the FDI-induced inequality influence doesn't quite apply as it's less potent in high-income nations relative to middle-income economies. Although the study cannot provide solid evidence of the harmful impact of captured centres on the inequality of income inside the world, highly qualified workers are intensively outsourcing services, which may lead to blurring the lines around unqualified and qualified workers in developing countries.

Ngwakwe and Dzomonda (2018) research outcome shows there is no long-run association between income inequality and the flows of foreign direct investment to South Africa during the time series studied. The study argues that more research should investigate the possible impact of governance on income disparity by integrating the governing factor into the design of co-integration regression to see if South African democratic governance could have led to growing income inequality Further study may also analyze the features of the flow of foreign direct investment into the nation to see if it does have features, such as FDI output, that could generate employment for local people. 
Bandyopadhyay (2018) investigate between time series properties of relative and absolute Gini coefficient. The outcome indicates that for fractionally integrated process the absolute Gini is more appropriate than relatively Gini for time-dependent analysis. Also, the study explored the estimate of the inequality-growth relation utilizing famous panel regression methods and found that with most estimated models, the absolute Gini is negatively and significantly correlated with the development and nothing for relative Gini.

Ryu (2008) and Ryu (2013), modified the definition of the Gini by defining an inconvenient degree with the inverse income value, whereby greater income offers more ease and lower-income offers a serious discomfort. The modification was due to the belief that the original Gini was observed to be less responsive to minor income shifts in the impoverished category to and that a decline in Gini would not be an increase for the impoverished group. The Bonferroni (1930) and Atkinson (1970) proposed a measure of inequality among various significant judgments to quantify inequality where zero value reflects the nonchalance to inequality and the Rawlsian measure is defined by infinity.

Also, Ravinthirakumaran and Ravinthirakumaran (2018) assessed the impact of foreign direct investment (FDI) inflows on income inequality in Asia-Pacific Economic Cooperation (APEC) economies. The ARDL results of the panel indicate that FDI inflows minimize income inequality longer term. This strengthens the belief that supporting FDI inflows in APEC economies may not damage revenue dispersion. The findings also support that per capita GDP and trade accessibility help minimize income inequality, while human capital increases income inequality. The findings of this research reflect those sound policies to attract more FDI should be introduced by the APEC authorities, as findings suggest that these inflows would minimize income inequality in the economies of APEC.

\subsubsection{Theoretical Review}

Foreign Direct Investment is when a foreign company or individual investor invests in the majority stocks or shares of another a company outside their home country. Horizontal foreign direct investment and vertical foreign direct investment are two forms of foreign direct investment.

Gini (1912) is credited with the development of the Gini index or Gini coefficient which was published in his 1912 paper Variability and Mutability. This index is the key indicator of inequality widely used in the field of economics and is used in many fields of research recently. Dalton (1920) in a later study used the index when analysing the distribution of income.

Theoretically, the two key ways to measure the Gini index are discrete and continuous distributions. Dorfman (1979) reported that both methods can be combined and Yitzhaki and Schechtman (2005) verified that it is simpler to develop continuous distribution in comparison to the discrete random variable. Needleman (1978) explored different ways of generating more reliable Gini coefficient estimates. An exact interval estimate of the Gini coefficient was given by Gastwirth (1972) and the Gini was compared with Tepping's findings to determine the precision of the estimates.

\subsubsection{Theories of FDI}

In this section, theories of FDI are reviewed from three perspectives. The first theory seeks to analyse why a company will favour foreign direct investment as a method of entering a foreign market. The other theory attempts to explain why companies in the same industry often undertake FDI at the same time, and why certain locations are favoured as a target for foreign direct investment over others. The third theoretical viewpoint, referred to as the eclectic model, seeks to incorporate the other two viewpoints into a single holistic FDI interpretation.

The theory of foreign direct investment in the manufacturing sector is typically applied distinctly from the FDI theory in the producer service. Baltagi et al. (2007) and Uttama and Péridy (2009) in their theoretical implications, pointed out the significant role of bilateral- and third-country characteristics and economic integration on bilateral complex FDI. Thet extended the Knowledge Capital (KC) model to explains the determinants of FDI in producer services. To motivate our empirical analysis of the impacts of foreign direct investment in producer services, this Their extended KC model investigate the bilateral and third-country determinants of FDI in producer services. Two goods are assumed in the KC namely homogeneous (Y) and differentiated (X) goods. Three countries were also assumed in the model namely the home (i), host (j) and third (k) country and four factors namely physical capital (K), skilled labour (S), unskilled labour (L) and producer services (Q). Homogeneous goods are produced with constant returns to scale and perfect competition by using unskilled labour only. Conversely, the production of the differentiated good uses the four factors. Producer services are produced with scale economies by using only skilled labour and are assumed that one unit of producer services is performed for one unit of goods to be consumed. 


\section{Method}

This section of the work presents the methodology of the study. The different approaches and methods used in analysing data.

\subsection{Data Source}

The study extracted data on the Gini coefficient from Trading Economics, Foreign Direct Investment (FDI), Trade openness and remittance from World Bank Indicator variables. The data consist of annual data point of Foreign Direct Investment, Trade openness and remittance from 1980 to 2015. However, not all the data point of the Gini coefficient was obtained from Trading Economics, hence the researcher replaced the missing value by using the linear interpolation method.

\subsection{Gini Coefficient}

Gini coefficient is a measure of inequality of income distribution among people living in a geographical area. Gini (1912) defined the Gini coefficient as a ratio with values between 0 and 1 . Where 1 refers to perfect income distribution inequality with few people possessing most of the income, while 0 refers to perfect income distribution equality with everyone having the same income share.

Gini coefficient is defined as a ratio of the areas on the Lorenz curve diagram. If the area between the line of perfect equality and Lorenz curve is $\mathrm{A}$, and the area under the Lorenz curve is $\mathrm{B}$, then the Gini coefficient is $\mathrm{A} /(\mathrm{A}+\mathrm{B})$. Since $A+B=0.5$, the Gini coefficient, $G=2 A=1-2 B$. If the Lorenz curve is represented by the function $\mathrm{Y}=\mathrm{L}(\mathrm{X})$, the value of $\mathrm{B}$ can be found with integration following equation 1 .

$$
G=1-2 \int_{0}^{1} L(x) d x
$$

Where $G$ is the Gini coefficient $L$, is the Lorenz Curve

\subsection{Unit Root Test}

According to Charemza and Deadman (1992), most macroeconomic time series data are known to be non-stationary. A data is said to be non-stationary if its mean and variance are not constant over time. The stationarity for each study variable was ascertained using the Augmented Dickey-Fuller (ADF) and the Phillips and Perron (PP) tests.

\subsubsection{Augmented Dickey-Fuller (ADF) Test}

The error terms are assumed to be uncorrelated and thus amounts to white noise in the traditional Dickey-Fuller test. Given the possibility of the error terms being correlated, an improved version of the traditional Dickey-Fuller was developed: Augmented Dickey-Fuller (ADF), where the error terms were assumed to be correlated. Because the error terms of several macroeconomic variables are likely to be correlated as series are often trended (Asteriou \& Hall, 2011), the ADF test is more useful in macroeconomic time series data. This test includes a lagged term of the dependent variable in the model to address any potential issue of autocorrelation. The generalized form of the ADF test may be specified as follows:

$$
\Delta Y_{t}=\alpha_{0}+\alpha_{1} Y_{t-1}+\alpha_{1} t+\sum_{j=1}^{p} Y_{j} \Delta Y_{t-j}+\varepsilon_{t}
$$

Where $\mathrm{Y}$ is the data series and $\Delta Y$ is the difference between the data.

\subsection{Cointegration Test}

If variables are found to be non-stationary at level but are stationary at the first difference there is a high possibility that they move together in the long run. The Engle (1982) procedure or the Johansen-Juselius procedure (Johansen, 1988; Johansen-Juselius, 1992, 1999) can be applied to overcome the associated problem of spurious correlation and misleading inferences. If the variables are found to be cointegrated, the relationship may be interpreted as a long-run relationship. However, in this study, the Johansen-Juselius procedure was used. The null hypothesis is given as $\left(H_{0}\right)$; $[\mathrm{r}=0 \sim 4]$ : There is cointegration among the variables can be drawn. Given a maximum rank $\mathrm{r}$, when the trace statistic is greater than $5 \%$ critical value, the study rejects the null hypothesis and conclude that there is cointegration among variables in the time series. The result of the trace test indicates no cointegrated vector. Johansen (1988) and Johansen and Juselius (1990) develop two test statistics to determine the number of cointegrating vectors. The Trace and Maximal Eigenvalue statistics are captured in equations 3 and 4 .

$$
\lambda_{\text {Trace }}(r)=-T \sum_{i=r+1}^{k} \ln \left(1-\hat{\lambda}_{i}\right)
$$


And the second is called Maximal Eigenvalue:

$$
\lambda_{\text {Max }}(r, r+) 1=-T \ln \left(1-\hat{\lambda}_{r+1}\right)
$$

where $T$ represent the number of observations, $r$ represent the number of cointegrating vectors and $\lambda$ is estimated eigenvalue.

In a situation where trace and Maximal Eigenvalue yield contradiction results, a trace is preferable (Alexander, 2001).

\subsubsection{Vector Error Correction Model}

Vector error correction model (VECM) is estimated to examine long-run and short-term causality dynamics among the variables. The VECM model is modelled as follows:

$$
\Delta \text { InGini }_{t}=\alpha+\lambda \varepsilon_{t-1}+\sum_{i=1}^{n} \mu_{i} \Delta F D I_{t-i}+\sum_{i=1}^{p} \gamma_{i} \Delta r \text { e } m_{t-i}+\sum_{i=1}^{m} v_{i} \Delta \text { topen }_{t-i}+\varepsilon_{t}
$$

where $\mu_{i}, \gamma_{i}, v_{t}$ represent the coefficient for Foreign Direct Investment, Remittance and Trade openness respectively; $\varepsilon_{t-1}$ represent the vector error correction model and $\varepsilon_{t}$ is the error correction term which reflects the deviation from the long-run equilibrium path. This allows causality to be determined in two ways namely: Short-run causality, which is determined by the lagged differences of the variables and; Long-run causality, which is determined by the significance of the coefficient of the error-correction term.

\section{Results}

This section presents the results of the analysis of the effect of Globalization on Ghana income distribution. The data was tested for its suitability for time series analysis hence, a Durbin-Watson Test was carried out to understand the nature of data as well as time series plot. Trend analysis, Co-integration and Vector Error Correction model were all done to achieve the stated objectives.

\subsection{Descriptive Statistics}

Descriptive statistics such as mean, standard deviation, skewness and kurtosis of all the variables are presented to provide a general overview and the basic characteristics of the data in the study. The results are presented in Table 1.

Table 1. Descriptive statistics of the study variables

\begin{tabular}{ccccccc}
\hline Variables & Min. & Max. & Mean & Std. Deviation & Skewness & Kurtosis \\
\hline Remittances & 500000 & 4982442361.79 & 442062449.61 & 1035129796.51 & 2.970 & 9.863 \\
FDI & 2000000 & 3363389444.44 & 775439361.13 & 1238264644.96 & 1.355 & .037 \\
Trade Openness & 0.0001 & 4.1440 & 0.689875 & 1.1199091 & 1.953 & 3.105 \\
Gini Index & 0.3530 & 0.4280 & 0.401731 & 0.0239361 & -0.508 & -1.076 \\
\hline
\end{tabular}

Source: World bank.

From table 1, the arithmetic mean and standard deviation of Remittances, FDI, Trade Openness and Gini Index was 442062449.61 ( $\mathrm{SD}=1035129796.51), 775439361.13(\mathrm{SD}=1238264644.96), 0.689875(\mathrm{SD}=1.119909)$ and $0.401731(\mathrm{SD}=0.0239361)$ respectively. Also, the study estimated the skewness and kurtosis of the study variables. According to Wooldridge (2002), if skewness is less than -1 or greater than +1 , the distribution is highly skewed. Thus, Remittance (2.970), FDI (1.355) and Trade Openness (1.953) are positively skewed since their respective Pearson Coefficient of skewness exceed 1, but Gini index is approximately symmetric since Pearson Coefficient of skewness value (-0.508) spanned between -0.5 to 0.5 .

A distribution with kurtosis $>3$ (excess kurtosis $>0$ ) is called leptokurtic. Compared to a normal distribution, its tails are longer and fatter, and often its central peak is higher and sharper. Kurtosis value for Remittance (9.863) and Trade Openness (3.105) exceeds 3, thus Remittance and Trade Openness were classified as leptokurtic. Also, the kurtosis value for FDI (0.037) and Gini Index (-1.076) was less than 3 and therefore are classified as Platykurtic.

\subsection{Trend Analysis}

The study adopted a trend analysis to investigate the behaviour of the study variables.

\subsubsection{Trend Analysis of Gini Coefficient}

Figure 1 displays the pictorial view of trend analysis of the Gini index. 


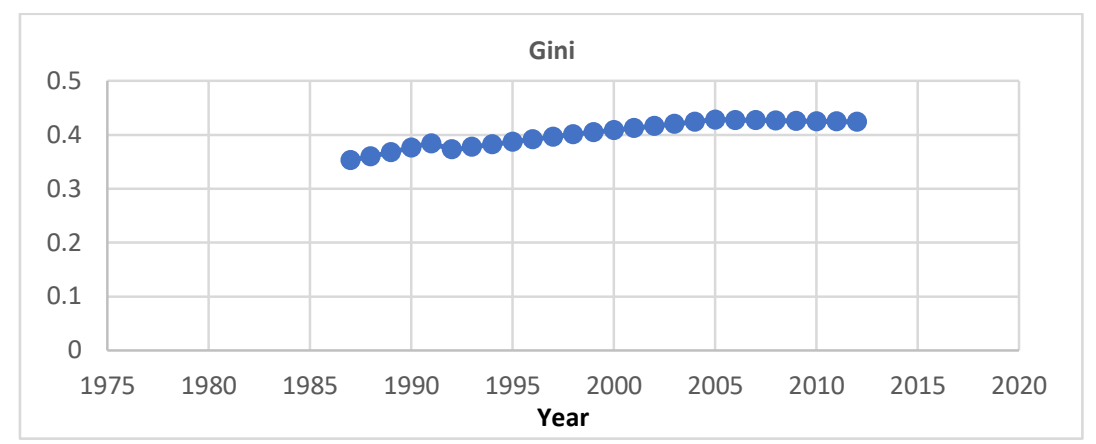

Figure 1. Trend analysis of the Gini coefficient

Source: Trading Economics.

The trend of Gini index revealed that there was a sharp increase from the year 1987 to the year 1992 . However, the sharp decrease from the year 1993 to the year 1994. Since the year 1994 to the year 2014, there has a steady increase in the Gini Index.

\subsubsection{Trend Analysis of Remittance and FDI}

The study examined the trend analysis of Remittance and FDI from 1980 to 2016 and the results are graphically presented in Figure 2.

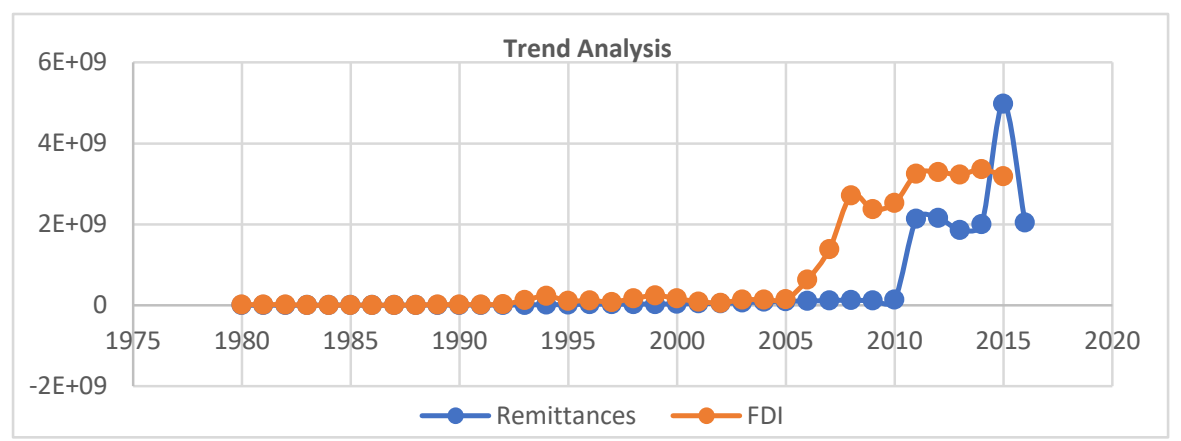

Figure 2. Trend analysis of Remittance and FDI

Source: Trading Economics.

This study's analysis suggests that from the year 1980 to 2005, the values for Remittance and FDI were approximately the same across this period. In Ghana, workers' remittances play a critical role in developing economy growth. From the year 2005 to the year 2010, FDI experienced a steady increase, whiles Remittance was relatively low and stable. However, Ghana witnessed a rapid flow in remittance at the end of 2012 and continued till 2015 and a sharp the decrease the subsequent year. Also, from the year 2010 to the year 2015, both Remittance and FDI experience fluctuation in their respective values.

\subsection{Unit Root Test}

Unit root test for stationary using Augmented Dicker-Fuller (ADF) test and Phillips-Perron's test are presented in Table 2. The rationale for testing for unit root test is based on the fact that stationarity of a series can strongly influence the behaviour and properties of variables and ultimately associations or interactions being verified.

Table 2. Unit root test

\begin{tabular}{ccccc}
\hline & \multicolumn{2}{c}{ ADF test statistic } & \multicolumn{2}{c}{ P-P test statistic } \\
\cline { 2 - 5 } Variables & Level & First Difference & Level & First Difference \\
\hline lngini & $-12.967^{*}$ & $-3.980^{* *}$ & $-2.972^{*}$ & $-7.278^{* *}$ \\
rem & -2.128 & $-8.687^{* *}$ & -1.940 & $-8.855^{* *}$ \\
fdi & 0.559 & $-4.488^{* *}$ & 0.276 & $-4.501^{* *}$ \\
topen & 6.308 & $-3.076^{*}$ & 11.073 & $-2.980 *$ \\
\hline
\end{tabular}

$* * \mathrm{p}<0.01, * \mathrm{p}<0.05$. 
Remittance, FDI, Trade Openness and Gini index variables are tested for unit root using Augmented Dickey-Fuller (ADF) and Philip-Perron's (P-P) unit root tests and the results can be seen in Table 2. The results show that all the study variables (Remittance, FDI, Trade Openness and Gini index), are integrated of order one I(1). This implies that at the level they were not stationary except at first difference. Thus, they are cointegrated, there is a long-term equilibrium relationship between the variables.

\subsection{Test of Co-Integration}

To test for cointegration, Johansen's test for cointegration.

Table 3. Johansen's test for cointegration

\begin{tabular}{cccccc}
\hline Maximum Rank & Parms & LL & Eigen & Trace Statistic & Critical Value \\
\hline 0 & 20 & 56.6257 & & 50.0006 & 47.21 \\
$\mathbf{1}$ & $\mathbf{2 7}$ & $\mathbf{7 0 . 0 2 3 7}$ & $\mathbf{0 . 6 7 2 5 8}$ & $\mathbf{2 3 . 2 0 1 4 6 *}$ & $\mathbf{2 9 . 6 8}$ \\
2 & 32 & 77.1753 & 0.44897 & 8.9013 & 15.41 \\
3 & 35 & 81.3517 & 0.29392 & 0.5487 & 3.76 \\
4 & 36 & 81.626 & 0.0226 & & \\
\hline
\end{tabular}

The Maximum Eigenvalue and Trace tests of cointegration from table 3 suggest a cointegration vector among the variables since at rank 1, the trace statistics is less than the $5 \%$ critical value. This implies that the null hypothesis that there is one cointegration must not be rejected. Thus, there is a long-run relationship between the Gini coefficient (income distribution) and independent variables.

\subsection{Vector Error Correction Model}

Cointegration analysis suggested the existence of a long-run relationship among the variables. Consequently, Vector error correction model is performed using the first lag of the variables. The result is presented in Tables 4 and 5 .

Table 4. VECM model summary

\begin{tabular}{cccc}
\hline RMSE & R-square & Chi-square & p-value \\
\hline 0.007899 & 0.6986 & 41.72373 & 0.0000 \\
\hline
\end{tabular}

From Table 4, the p-value of the chi-square is significant, suggesting that the model is significant. Also, the $\mathrm{R}$-square value of 0.6986 , indicating that $69.86 \%$ of the variation of the Gini coefficient could be explained by the independent variable.

Table 5. Vector error correction model

\begin{tabular}{ccccccc}
\hline Model & Coeff & Std Err & z-statistic & p-value & \multicolumn{2}{c}{$95 \%$ Conf Interval } \\
\hline$\Delta E C T_{t-1}$ & -0.8513 & 0.1916 & -4.44 & 0.000 & -1.2268 & -0.4758 \\
$\Delta$ lngini $_{t-1}$ & 0.1734 & 0.1555 & 1.12 & 0.265 & -0.1314 & 0.4781 \\
$\Delta$ rem $_{t-1}$ & -0.0076 & 0.0031 & -2.43 & 0.015 & -0.1381 & -0.0014 \\
$\Delta$ fdi $_{t-1}$ & 0.0052 & 0.003 & 1.73 & 0.084 & -0.0007 & 0.01101 \\
topen $_{t-1}$ & 0.005 & 0.0129 & 0.39 & 0.698 & -0.0203 & 0.03039 \\
Constant & -0.2613 & 0.0071 & -3.67 & 0.000 & -0.0401 & -0.0121 \\
R-square & 0.6986 & & & & & \\
Chi-square & 41.7237 & & & & & \\
P-value & 0.0000 & & & & & \\
RMSE & 0.0079 & & & & & \\
\hline
\end{tabular}

From Table 5, the coefficient of the error correction term (ECT) was negative and significant as the p-value was less than 0.005 . This implies that $85.13 \%$ of the short-run disequilibrium adjusts to the long-run equilibrium annually for income distribution (Gini coefficient).

The study also found out that, there was a significant ( $p$-value $=0.015$ ) negative (Coefficient $=-0.076$ ) relationship between foreign remittance and income distribution. This implies that an increase in foreign remittance will widen the income distribution gap and vice versa. 
However, the result revealed that FDI inflow has a positive (coefficient $=0.0052$ ) relationship with income inequality but statistical insignificance since the p-value $(0.082)$ is beyond 0.05 . In the other hand, Chanthavong (2017) found that internationalization represented by the FDI inflow has a positive relationship with the Gini coefficient.

\section{Discussion}

The first hypothesis that there is no significant relationship between foreign remittance and income distribution is 1 rejected at 5\%. There was a significant negative relationship, this implies that an increase in foreign remittance will widen the income distribution gap and vice versa. This result is consistent with Yomogidam and Zhaot (2010), they explained that higher-income families can go to abroad and had a lot of family members and friends in abroad. Hence, receive more remittance than poor families and as a result widen the already existing gap between the rich and poor. The results favour the conventional wisdom that opens up the economy into the international market has some distributional effects in favour of the lower-income groups. The study finds that foreign capital penetration either through remittances harms income inequality. The other dimension of the globalization also supports conventional wisdom. Bandyopadhyay (2018), estimation of the inequality-growth relationship using popular panel regression methods and find that the absolute Gini is negatively and significantly associated with growth for most models estimated.

The second hypothesis state that there is no significant relationship between FDI inflow and income inequalities was not rejected at 5\%. This result contrasts with Chanthavong (2017), who found out that FDI inflow has a significant positive relationship with the income inequalities.

\section{Policy Implication}

At the level of policy, our results suggest that the income inequality over the years are increasing, the government need to diversify their resources on bridging the poverty gaps. Since foreign remittance widens income inequality, the government must put measures so that some of the foreign remittances will be channelled to the poor ones.

\section{References}

Antràs, P., De Gortari, A., \& Itskhoki, O. (2017). Globalization, inequality and welfare. Journal of International Economics, 108, 387-412. https://doi.org/10.1016/j.jinteco.2017.07.009

Bandyopadhyay, S. (2018). The absolute Gini is a more reliable measure of inequality for time dependent analyses (compared with the relative Gini). Economics Letters, 162, 135-139. https://doi.org/10.1016/j.econlet.2017.07.012

Benería, L., Berik, G., \& Floro, M. (2015). Gender, development and globalization: Economics as if all people mattered. Routledge. https://doi.org/10.4324/9780203107935

Bergh, A., \& Nilsson, T. (2014). Is Globalization Reducing Absolute Poverty? World Development, 62, 42-61. https://doi.org/10.1016/j.worlddev.2014.04.007

Bhagwati, J., \& Srinivasan, T. N. (2002). Trade and poverty in the poor countries. American Economic Review, 92(2), 180-183. https://doi.org/10.1257/000282802320189212

Brambilla, C., Laine, J., \& Bocchi, G. (2016). Introduction: Thinking, mapping, acting and living borders under contemporary globalisation Borderscaping: Imaginations and Practices of border making (pp. 19-28): Routledge. https://doi.org/10.4324/9781315569765

Chanthavong, M. S. (2017). Inequality and Economic Development in Lao Pdr Since The 1986 Economic Reform (Doctoral Dissertation, Thammasat University).

Chen, C., Zhao, H., \& Zhou, Y. (2017). Foreign direct investment and wage inequality: Evidence from the People's Republic of China (ADBI Working Paper No. 734). Tokyo: Asian Development Bank Institute.

Couto, V., \& Center, G. V. C. (2018). Does Foreign Direct Investment Lower Income Inequality? New Evidence and Discussion on the Role of Service Offshoring (Captive Centers). Retrieved from https://digitalcommons.ilr.cornell.edu/intl/611/

Dalton, H. (1920). The measurement of the inequality of incomes. The Economic Journal, 30(119), 348-361. https://doi.org/10.2307/2223525

Damgaard, C., \& Weiner, J. (2008). Modeling the growth of individuals in crowded plant populations. Journal of Plant Ecology, 1(2), 111-116. https://doi.org/10.1093/jpe/rtn008 
Darkwah, K. A., Nortey, E. N., \& Lotsi, A. (2016). Estimation of the Gini coefficient for the lognormal distribution of income using the Lorenz curve. SpringerPlus, 5(1), 1196. https://doi.org/10.1186/s40064-016-2868-z

Daumal, M. (2013). The impact of trade openness on regional inequality: the cases of India and Brazil. The International Trade Journal, 27(3), 243-280. https://doi.org/10.1080/08853908.2013.796839

Dollar, D., \& Kraay, A. (2004). Trade, Growth, and Poverty. The Economic Journal, 114(493), F22-F49. https://doi.org/10.1111/j.0013-0133.2004.00186.x

Fellman, J. (2012). Estimation of Gini coefficients using Lorenz curves. Journal of Statistical and Econometric Methods, 1(2), 31-38.

Flach, L., \& Janeba, E. (2017). Income inequality and export prices across countries. Canadian Journal of Economics/Revue canadienne d'économique, 50(1), 162-200. https://doi.org/10.1111/caje.12254

Fouquin, M., \& Hugot, J. (2016). Two centuries of bilateral trade and gravity data: 1827-2014 (No. 015129). Universidad Javeriana-Bogotá.

Gastwirth, J. L. (1972). The estimation of the Lorenz curve and Gini index. The Review of Economics and Statistics, 306-316. https://doi.org/10.2307/1937992

Gini, C. (1912). Variabilità e mutabilità. In E. Pizetti, \& T. Salvemini (Eds.), Memorie di metodologica statistica. Rome: Libreria Eredi Virgilio Veschi.

Golden, J. (2008). A simple geometric approach to approximating the Gini coefficient. The Journal of Economic Education, 39(1), 68-77. https://doi.org/10.3200/JECE.39.1.68-77

Gourdon, J. (2011). Openness and inequality in developing countries: A new look at the evidence. Retrieved from https://halshs.archives-ouvertes.fr/halshs-00557117

Hipsher, S. (2017). Poverty Reduction and Wealth Creation. In Poverty Reduction, the Private Sector, and Tourism in Mainland Southeast Asia (pp. 55-79). Palgrave Macmillan, Singapore. https://doi.org/10.1007/978-981-10-5948-3_3

Hirst, P., Thompson, G., \& Bromley, S. (2015). Globalization in question. John Wiley \& Sons.

Kendall, M. G., \& Stuart, A. (1958). The Advanced Theory of Statistics (Vol. 1).

Kirby, P. (2013). Vulnerability and globalization: The social impact of globalization. The Routledge International Handbook of Globalization Studies (pp. 136-156): Routledge.

Mahesh, M. (2011). The Effect of Trade Openness on Income Inequality: Evidence from Developing Countries. https://doi.org/10.2139/ssrn.2736721

Mahesh, M. (2016). The effects of trade openness on income inequality-evidence from BRIC countries. Economics Bulletin, 36(3), 1751-1761.

Markusen, J. (2005). Modeling the offshoring of white-collar services: From comparative advantage to the new theories of trade and FDI (No. w11827). National Bureau of Economic Research. https://doi.org/10.3386/w11827

Markusen, J. R., \& Strand, B. (2009). Adapting the Knowledge-capital Model of the Multinational Enterprise to Trade and Investment in Business Services. World Economy, 32(1), 6-29. https://doi.org/10.1111/j.1467-9701.2009.01155.x

Milanovic, B. (2016). Global inequality: A new approach for the age of globalization. Harvard University Press. https://doi.org/10.4159/9780674969797

Morgan, J. (1962). The anatomy of income distribution. The Review of Economics and Statistics, 270-283. https://doi.org/10.2307/1926398

Ngwakwe, C. C., \& Dzomonda, O. (2018). Foreign Direct Investment Inflow and Inequality in an Emerging Economy-South Africa. Economica, 14(2).

Pieterse, J. N. (2019). Globalization and culture: Global mélange. Rowman \& Littlefield.

Ravinthirakumaran, K., \& Ravinthirakumaran, N. (2018). The impact of foreign direct investment on income inequality: A panel Autoregressive Distributed Lag approach for the Asia-Pacific Economic Cooperation developing economies. Asia-Pacific Sustainable Development, 57. https://doi.org/10.18356/d30b620b-en

Rivera, C. G. J., \& Castro, G. Á. (2013). Foreign direct investment in Mexico Determinants and its effect on 
income inequality. Contaduríay Administración, 201-222. https://doi.org/10.1016/S0186-1042(13)71239-7

Ryu, H. K. (2013). A bottom poor sensitive Gini coefficient and maximum entropy estimation of income distributions. Economics Letters, 118(2), 370-374. https://doi.org/10.1016/j.econlet.2012.11.018

Sarti, R. (2008). The globalisation of domestic service: An historical perspective. Migration and domestic work: A European perspective on a global theme, 77-98.

Sen, A. (1973). Behaviour and the Concept of Preference. Economica, 40(159), 241-259. https://doi.org/10.2307/2552796

Stromquist, N. P., \& Monkman, K. (2014). Globalization and education: Integration and contestation across cultures. R\&L Education.

Suanes, M. (2016). Foreign direct investment and income inequality in Latin America: A sectoral analysis. Cepal Review. https://doi.org/10.18356/13c68e36-en

Surugiu, M. R., \& Surugiu, C. (2015). International trade, globalization and economic interdependence between European countries: Implications for businesses and marketing framework. Procedia Economics and Finance, 32(15), 131-138. https://doi.org/10.1016/S2212-5671(15)01374-X

Uttama, N. P., \& Peridy, N. (2009). The impact of regional integration and third-country effects on FDI: Evidence from ASEAN. ASEAN Economic Bulletin, 239-252. https://doi.org/10.1355/AE26-3A

Wilhelmina, Q., Joost, J., George, E., \& Guido, R. (2010). Globalization vs. localization: Global food challenges and local solutions. International Journal of Consumer Studies, 34(3), 357-366. https://doi.org/10.1111/j.1470-6431.2010.00868.x

$\mathrm{Wu}$, J. Y., \& Hsu, C. C. (2012). Foreign direct investment and income inequality: Does the relationship vary $\begin{array}{llll}\text { with absorptive } \quad \text { capacity? } & \text { Economic }\end{array}$ https://doi.org/10.1016/j.econmod.2012.06.013

Xu, K., \& Osberg, L. (2002). The social welfare implications, decomposability, and geometry of the Sen family of poverty indices. Canadian Journal of Economics/Revue Canadienne D'économique, 35(1), 138-152. https://doi.org/10.1111/1540-5982.00124

Yenipazarli, A., \& Kucukkaya, H. (2016). Does the Impact of Trade Openness on Income and Income Inequality Differ in Developed and Developing Countries? Entrepreneurship, Business and Economics, 2, 479-489. https://doi.org/10.1007/978-3-319-27573-4_32

Yitzhaki, S., \& Schechtman, E. (2005). The properties of the extended Gini measures of variability and inequality. https://doi.org/10.2139/ssrn.815564

\section{Copyrights}

Copyright for this article is retained by the author(s), with first publication rights granted to the journal.

This is an open-access article distributed under the terms and conditions of the Creative Commons Attribution license (http://creativecommons.org/licenses/by/4.0/). 